\title{
Social Representations of Physical Education and Sports in Gabonese Primary School Teachers
}

\author{
Jean Itoua Okemba1,2*, Irène Oye Essono ${ }^{3}$, Jean Georges André Moulongo ${ }^{4}$, Alphonse Massamba ${ }^{4}$ \\ ${ }^{1}$ Laboratoire de Didactique des Activités Physiques et Sportives, Institut Supérieur de l' Education Physique et Sportive (ISEPS), \\ Université Marien Ngouabi, Brazzaville, Congo \\ ${ }^{2}$ Chaire UNESCO en Sciences de l'Education pour l' Afrique Centrale, Ecole Normale Supérieure (ENS), Université Marien Ngouabi, \\ Brazzaville, Congo \\ ${ }^{3}$ Institut National de la Jeunesse et des Sports, Libreville, Gabon \\ ${ }^{4}$ Laboratoire de Biosciences appliquées au sport, Institut Supérieur de l' Education Physique et Sportive (ISEPS), Université Marien \\ Ngouabi, Brazzaville, Congo \\ Email: ^itoua_okemba@yahoo.fr
}

How to cite this paper: Itoua Okemba, J., Essono, I.O., Moulongo, J.G.A. and Massamba, A. (2016) Social Representations of Physical Education and Sports in Gabonese Primary School Teachers. Open Journal of Social Sciences, 4, 165-175.

http://dx.doi.org/10.4236/jss.2016.410013

Received: September 29, 2016

Accepted: October 28, 2016

Published: October 31, 2016

Copyright $\odot 2016$ by authors and Scientific Research Publishing Inc. This work is licensed under the Creative Commons Attribution International License (CC BY 4.0).

http://creativecommons.org/licenses/by/4.0/ (c) (i) Open Access

\begin{abstract}
The purpose of this study is to identify and analyze the social representations of primary school teachers in Gabon on the teaching of physical education (EPS). This qualitative study carried on 54 teachers ( 38 women and 16 men) focused on the school district of the Estuary. The studied variables were the professional training, knowledge of official texts, teaching materials used, the role of EPS in primary school, educational practices and evaluation of EPS of primary school in Gabon and challenges for the teaching of EPS. The results obtained indicated: 1) the scarcity of training and educational support (70\% of reports); 2) ignorance of official teaching texts of the EPS in the primary division (88.9\% of reports); 3 ) the presence of a monthly annual programming for teaching the discipline for $+68.6 \%$ of teachers; 4 ) inadequate sports infrastructure, educational materials and documentation; 5) respect of the regulatory texts $(64.8 \%$ of teachers); 6 ) lack of teaching method for the teaching of EPS (80\% of sales); 7) non-participation in the competitions organized by FEGASS. These results show that in Gabon, the teaching of physical education and sports of primary cycle reveals many difficulties compared to other disciplines.
\end{abstract}

\section{Keywords}

Representations, Physical Education, Primary School, Teacher

\section{Introduction}

The present research work which is focused on social representations of physical edu- 
cation and sports (EPS) among primary school teachers in Estuary province (Gabon). It was prompted by our experience since graduate diploma obtained in the National Institute of Youth and Sports (INJS) in Libreville in 1999. We exerted functions of pedagogic councilor respectively in Quaben College, Bessieux College, OMAR BONGO Technical School National and Jean-Hilaire Aubame EYEGHE high school.

From 1999 to 2014, we were transferred to the school district of the Estuary for occupying EPS pedagogical framer functions. During the various missions in the schools of this district, we observed that the EPS didn't occupy the same place as other school subjects. It appeared that throughout our many years' experience, EPS teaching in primary school was assured sometimes sporadically or irregularly, while a place was it indeed reserved in the schedules. Such failure seemed surprising to us especially as among the subjects taught in primary schools, the EPS was seen as one that promotes the integral development of the student by providing both physical fulfillment and intellectual formation. Indeed, more than any other social institution, school plays a leading role in the socialization of students it houses [1] [2]. These factors characterize the functioning of the institution. This role also comes to the purposes that inspire the educational process as a whole. He finally explained by the objectives of the teaching/ learning of school subjects, especially EPS; these objectives must, through content and skills, improve mental, social, psychological and physical capacities of students, as function as translate and deductions purposes [3] [4]. Thus, these academic topics improve knowledge transmitted to students, enabling them to acquire acting, being and thinking promoted by such purposes. However, it should be noted that despite their collective contribution to the socialization of students, all school subjects do not seem to enjoy the same consideration in the school. Urban schools appear privileged, while rural schools seem sidelined. So, government measures support the integration of EPS as a compulsory discipline in the Gabonese education system by relying on the official texts adopted for this purpose. Despite such measures, we noted that the EPS teaching is struggling to take root in the Gabonese education system taking into account the multifaceted challenges that hinder its implementation in schools and in classrooms. This condition reflected clearly the difficulties of these teachers to ensure the EPS teaching. It is in this context that we identify the representations of Gabonese teachers on the EPS in primary schools and the strategies deployed as decisive actors in the education system. Indeed, these teachers are responsible for translating, through learning situations, educational purposes to pupils [5]-[8]. In addition, a central issue is to improve the performances of educational actors and designate the true forms of action of the studied system. For this purpose, one of the criticisms made against the practice of EPS to primary education in Central Africa concerns the deletion of the actors [2] in sports within school structures. But, modern sport sociology has the characteristic to have, in contrast, rediscovered the place and role of the sports teacher at school. Moreover, this view is brought into the theoretical framework of social representations through examining the concept of the EPS or discipline, by multiple questions:

1) What are strategies of Educational Ministry on the development of EPS in Gabo- 
nese primary cycle?

2) What are the factors limiting the practice of EPS in primary school in Gabon?

3) What are representations of primary teachers on EPS teaching?

4) How do they put in daily work that they teach in their classes?

To answer these questions, we suppose that the dysfunction of the teaching of EPS in primary school in Gabon is linked with opinions, practices, attitudes and judgments about this scholar discipline, the quality sports facilities, the working conditions, the collaboration between teachers and educational authorities and the methods employed.

To our knowledge, there are no data in this field in Gabon. Hence, this work aims to analyze the social representations of primary school teachers in Gabon in comparison with EPS teaching. The specific objectives were multiple: 1) to understand the situation of EPS learning in primary school in Gabon; 2) to assess the opinions of key stakeholders of the education system in the place of this teaching as regarding how to take charge in relation to the conditions under the EPS practice; 3 ) to propose solutions for improving EPS teaching in Gabonese primary schools.

\section{Material and Methods}

\subsection{Type of Research}

This prospective and analytic study is associated with social representations of teachers. Furthermore, this study has a quantitative aspect to achieve the objectives.

\subsection{Time and Space for the Study}

The study was conducted from April 13 to May 15, 2016 in Estuary Province, among nine (09) provinces in Gabon. The choice of this province is linked to the workplace of fellow research. The Province of the Estuary is located north-east Gabon on horseback between Equatorial Guinea and Maritime Ogoué. It is bounded to the North by the Woleu-Ntem and Equatorial Guinea, to the East by the Middle Ogoué, to the West by the Atlantic Ocean and the South by the Ogoué Maritime (Figure 1).

As function as school cutting perspective, five (05) districts who make up the Province of the Estuary: 1) North District; 2) South District; 3) District Centre; 4) East District; 5) District Estuary. The school district Estuary has been selected by random drawing at $1 / 5$. So, three (03) departments were selected:

1) Department of KOMO-Mondah (capital: Ntoum);

2) Department of KOMO-KANGO (County seat: Kango);

3) Department of NOYA (County seat: Cocobeach).

These departments include 153 primary schools: 50 schools of public sector; 86 schools of secular private sector; 12 schools of catholic sector; 05 schools of protestant sector.

In total, data of Ministry of Education and Technical Education (2016) reported 1140 teachers and 28.957 pupils in these primary schools.

Among the 153 primary schools, two were selected in different sectors of learning. The so-called schools selection mode based on their geographical location, easy access, 


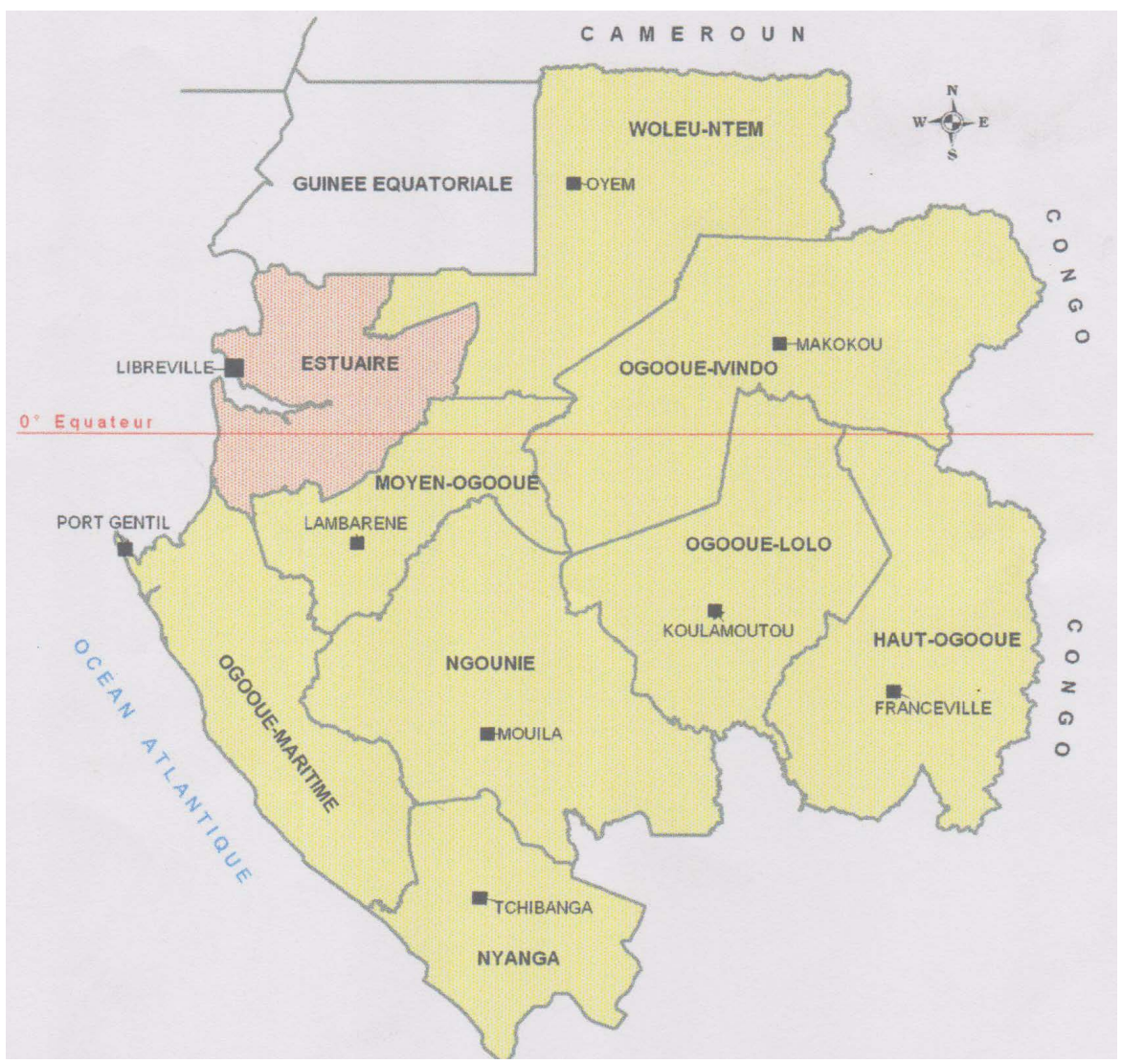

Figure 1. Map of Republic of Gabon and location of the province of the Estuary.

the high number of teachers, a full-time teaching position and center of evaluation of EPS practical examinations during the diploma of the Certificate of Elementary Primary Education (CPCE).

The primary public schools within these departments were Mondah Ntoum and Bikele primary school. As for private schools, we recruited:

1) secular private primary schools: primary school Sainte Clotilde and primary school La Martiniere.

2) Catholic Primary schools: Primary school Saint Luke Bikele and primary school Saint Thomas.

3) Protestant primary schools: primary school and primary school Nkoltang Melen II.

\subsection{Sampling}

Among 1140 teachers of both sexes [845 women (71.1\%) and 295 men (28.9\%)], 54 teachers (38 women and 16 men) took part in this study. A convenience sampling procedure was followed to select these subjects. Table 1 reports the distribution of subjects according to age and seniority in the profession. The inclusion criteria were volunteer to participate in the study and fully completed questionnaire. One year teaching experience in primary education was an exclusion criterion. They were divided into 27 public school teachers and 27 teachers from the private sector. 
Table 1. Distribution of teachers as function as seniority.

\begin{tabular}{ccc}
\hline & Number (n) & Percentage (\%) \\
\hline$<5$ ans & 09 & 16.7 \\
$5-10$ ans & 18 & 33.3 \\
$11-16$ ans & 20 & 37.0 \\
$17-22$ ans & 06 & 11.1 \\
$23-28$ ans & 00 & 00 \\
$>28$ ans & 01 & 01.9 \\
\hline
\end{tabular}

\subsection{Data Collection Instruments}

Like most studies on social representations of teachers in relation to a discipline [9] [10], the tool used to assess the social representations of Gabonese primary school teachers compared to the teaching of EPS was a questionnaire consisted of 14 items: dichotomous $(n=12)$ and open $(n=02)$.The questions were of various kinds:

- Fact: Information on facts which the teacher had the experience or with his knowledge;

- Action: data for the teacher if he accomplished certain acts related to the physical education;

- Intent which aimed to ask the teacher what he would do in a given circumstance teaching situation of physical education;

- Opinions to know what the teachers thought about a particular practice associated with the teaching of physical education in primary school.

The questionnaire included six (06) parts: 1) training (02 questions); 2) knowledge of official texts and avaibility of curricula (02 questions); 3 ) teaching materials used (03 questions); 4) role of EPS (02 questions); 5) teaching practices and participation of pupils in games organized by FEGASS (04 questions); 6) difficulties observed (01 question).

A preliminary survey was first conducted among twelve (12) of primary school teachers to check understanding of issues, consistency of items to validate the questionnaire. Furthermore, the $\alpha$ Cronbach index, equal to 0.88 , revealedthe consistency of questionnaire.

\subsection{Variables of Study}

This was to collect information and opinions of teachers on:

- The training course;

- Knowledge of official texts;

- The strategies used during their teaching practice;

- Student participation;

- Teaching practices;

- Participation in school sports;

- The planning of APSA;

- The purposes of the EPS; 
- The quality of sports facilities;

- The teaching materials used by teachers during PE classes;

- The existence of paper on the teaching of EPS in the primary cycle;

- The position of teachers in relation to the EPS practice during evaluation of CPCE;

- The wishes and suggestions of teachers to improve the EPS practice in the primary grades.

\subsection{Statistic Analysis}

Statistical techniques were used during the processing of the questionnaires. Thus, the indices of descriptive statistics were used to decrypt the responses from teachers: numbers, percentages. Furthermore, the percentages of comparison tests were required to identify different opinions for the same item. Test of Flahaut [11] was used for compare two ppercentages $\mathrm{p}_{1}$ and $\mathrm{p}_{2}$. For more than two percentages (here, $\mathrm{p}_{1}, \mathrm{p}_{2}$ and $\mathrm{p}_{3}$ ), the test $S$ of Sokal [12] was selected. Furthermore, the test chi-square $\left(\chi^{2}\right)$ was used to search the link between gender and the opinions of the respondents in relation to the compliance of official texts in the EPS practice in primary school.

The statistical significance of the two tests was set at $\mathrm{p}<0.05$. The software used for data processing was SPSS, version 12.5.1.

\section{Results}

\subsection{Professional Training}

Table 2 indicates the numbers and percentages of responses among teachers in relation to vocational training. As function as existence of initial training in the teaching of physical education in primary school, $59.3 \%$ of the respondents said thatthey had not received. However, the difference was no significant compared to those who had benefited. Among subjects who had not received initial training, $70 \%$ of them didn't received training or educational support. If educational support, resource persons were in descending order: school councilors (12 of 17 reports, or 70.6\%; $\mathrm{p}<0.001$ ); educational inspectors (04 of 17 reports, or 23.5\%); a high school teacher of EPS (01 of 17 reports or $5.1 \%)$.

Among the surveyed teachers who had not received initial training, they were found 17 teachers of public sector among 32 of items (53.1\%) against 15 teachers of private schools (45.9\%).

Table 2. Numbers and percentages of citations for vocational training.

\begin{tabular}{cccccccc}
\hline & \multicolumn{2}{c}{ Yes } & & No & t & P \\
\cline { 2 - 7 } & $\mathrm{n}$ & $\%$ & $\mathrm{n}$ & $\%$ & & \\
\hline $\begin{array}{c}\text { Existence of basic training for the teaching of } \\
\text { Physical education }\end{array}$ & 22 & 40.7 & 32 & 59.3 & 1,35 & NS \\
$\begin{array}{c}\text { Pedagogic support of a resource person } \\
\text { Total }\end{array}$ & 17 & 30.0 & 37 & 70.0 & 2,80 & $\mathrm{~S}^{*}$ \\
\hline
\end{tabular}

Abbreviations: NS, not significant difference; $\mathrm{S}^{*}$, significant difference at $\mathrm{p}<0.05$. 


\subsection{Knowledge of Official Texts}

The numbers and percentages of respondents on knowledge of official documents relating to the EPS teaching in primary school show that the official texts of the EPS teaching were in almost all cases $(88,9 \%)$ infringed by the respondents: $81.5 \%$ in the private sector and $96.3 \%$ in the sector public. This trend is also related to the lack of programming monthly or yearly for this discipline, as shown in the data in Table 3. In fact, $68.6 \%$ of respondents across all sectors had a monthly programming and/or annual for the teaching of physical education. However, if one refers to each education sector. No significant difference between the teachers was observed.

\subsection{Pedagogic Supports}

Concerning training materials, teachers reported reliable sports facilities $(83.8 \%$ of mentions), adapted learning materials ( $81.5 \%$ of citations) and appropriate teaching materials ( $91.1 \%$ of citations). The sports facilities were limited to found a football field, a jumper and a running track. The equipment consisted of a few soccer balls, weight to launch, ropes for the high jump, and the pads. The documents were to some worksheets, curricula target location guides and workbooks. One respondent reported the existence and use of a CONFEJES document to EPS teaching in primary school.

\subsection{Other Representations}

As for the role of EPS in primary school, the views of respondents on the place accorded students in EPS and this importance in primary schools revealed the attractiveness of all learners for this discipline, although in $11.1 \%$ of private school students surveyed say otherwise. Compared to importance of physical teaching in primary school, all of the respondents $(n=54 ; 100 \%)$ were recognized by all. The reasons given for this were: 1) the development of psychomotor skills in children; 2) the development of the learner through knowledge; 3) the taste of physical effort; 4) thealtruism; 5) thecompetitive spirit; 6) the discovery of talents by the child and/or the sports teacher; 7) thesocial cohesion; 8) thelove fun games; 9) the existence of a correlation between EPS and the student's daily life; 10) the psychosomatic balance; 11) thesocial inclusion among youth.

\subsection{Teaching and Evaluation in Physical Education in Primary School Practices}

As regards compliance with official texts in the teaching/learning of physical education at the primary school, $64.8 \%(\mathrm{p}<0.05)$ of respondents claimed to be in compliance with the regulations in their practices. However, according to the education sector, no significant difference was observed.

As function as representations of EPS among the disciplines selected for classroom assessments, data are reported in Table 4. According to official documents, all respondents $(\mathrm{n}=54 ; 100 \%)$ recognized that the EPS occupied the same rank among the disciplines selected for the primary cycle of evaluation and examinations in Gabon. The 
Table 3. Monthly or annual program for the teaching of physical education.

\begin{tabular}{ccccccc}
\hline & \multicolumn{2}{c}{ Yes } & & No & t & P \\
\cline { 2 - 7 } & $\mathrm{n}$ & $\%$ & $\mathrm{n}$ & $\%$ & & \\
\hline Public & 19 & 70,4 & 08 & 29.6 & 1,93 & NS \\
Private & 18 & 66,7 & 09 & 33.3 & 1,65 & NS \\
Total & 37 & 68,6 & 17 & 31.4 & 2,50 & $\mathrm{~S}^{*}$ \\
\hline
\end{tabular}

Abbreviations: NS, not significant difference; $\mathrm{S}^{*}$, significant difference at $\mathrm{p}<0.05$.

Table 4. Place of physical education during classroom assessments.

\begin{tabular}{ccccccc}
\hline & \multicolumn{2}{c}{ Yes } & & No & t & P \\
\cline { 2 - 7 } & $\mathrm{n}$ & $\%$ & $\mathrm{n}$ & $\%$ & \\
\hline Public sector & 27 & 100 & 00 & 00 & - & $\mathrm{S}^{* * *}$ \\
Private sector & 27 & 100 & 00 & 00 & - & $\mathrm{S}^{* * *}$ \\
Total & 54 & 100 & 00 & 00 & - & $\mathrm{S}^{* * *}$ \\
\hline
\end{tabular}

methods used in classes were based on:

- The collective game (05 reports);

- The target position of notebooks (03 reports);

- The disparity methods (01 report);

- The rate of stroke (01 report).

In summary, among the 54 surveyed teachers, $44(81.5 \%)$ of them didn't have the EPS teaching methods or didn't know.

As for participation in school competitions at the Gabonese Federation of School Sports (FEGASS), it appears that all schools didn't participate in competitions organized at national level by the FEGASS. The reasons given were: 1) lack of the FRGASS in rural area; 2) lack of information; 3) ignorance of the existence of the FEGASS; 4) neglect rural schools by FEGASS;5) lack of training; 6) bad quality of roads in rural area; 7) lack of infrastructure.

\section{Discussion}

The aim of this study was to identify the social representations of primary school teachers in Gabon over the teaching of EPS. The main results show that: 1) seven (07) out of 10 teachers $(70 \% ; \mathrm{p}<0.05)$ had not received further training or educational support; 2$) 88.9 \%(\mathrm{p}<0.001)$ teachers did not know the official texts of the teaching of EPS to primary education; 3$) 68.6 \%(\mathrm{p}<0.05)$ of respondents still had to monthly programming and/or annual for the teaching of this discipline; 4) sports facilities were almost nonexistent, limited to mostly a football field or a racetrack. Those that were found in poor condition; 5) teaching material was scarce, made for mostly by a few soccer balls, weights, ropes for the high jump and pads; 6) documentation were a few worksheets, the curriculum available to them and rarely to the existence of educational guides and specifications; 7) nearly all teachers recognized the importance of the practice of EPS in the cognitive, physical and psycho-social development of children; 8) 
64.8\% ( $\mathrm{p}<0.05)$ teachers' compliance with regulations; 9) EPS included indeed among the disciplines selected for competitions and examinations from primary to Gabon; 10) the methods used for teaching were largely non-existent ( $81 \%$ of reports); 11) no school participated in competitions organized by the FEGASS for reasons of remoteness, poor roads, lack of information and infrastructure; 12) the main difficulties of implementing educational strategies in rural primary school where infrastructures characterized by lack of material sand equipments.

However, our study has some weaknesses. The first result of the weakness sample (54 teachers). This doesn't allow extrapolating our results to all primary school teachers of Gabon. The second weakness may be attributed to the nature of the measuring instrument. Indeed, our survey included only questions either open or closed. It would have taken to diversify the types of questions: questions to evaluation questions range (multiple choices), indirect questions (used for fear that the respondent answers truthfully to the question asked). However, the writing of our questions was dominated by two fundamental concerns: get accurate answers, get answers; the content is not influenced by the wording of the question. These two concerns have been achieved by the implementation of a pre-investigation and the search for consistency issues ( $\alpha$ of Cronbach equal to 0.88 ). In addition, the juxtaposition of all issues as recommended in social science [13] was respected. Finally, the main strength of this work lies in the fact that our study is the first to our knowledge, which concerns the concept which teachers evolving in rural Gabon on the teaching of EPS.

It is clear from our results that the EPS to primary education is not treated like any other subject taught in school [14] [15]. She does not have a strong place in the Gabonese education system. In Gabon, this situation can be explained by the training of trainers failure. Besides, according to our personal investigations, most of these trainers had not sufficiently appropriate content and PSE programs at primary school, and did not know the role that was assigned. According Ntsame Edno "to be considered a true authentic teaching in the primary grades, the EPS must transform the object of his teaching in structured content, prioritized, evaluated permanently and if possible differentiated" ([16], p. 54). Thus, the EPS discipline in primary education in Gabon through all time, mainly rural crisis that we could call "recognition of a crisis". So, we need awareness to show that the EPS of education should have a privileged position as other educational disciplines during class councils, institutions. Therefore, in light of the findings of Ntsame Edno [16] and Pontais [17], knowledge promoted by the EPS should be divided between classes and lessons gradually depending on the degree of complexity they present. Thus, they will be planning that would spread their learning throughout the primary cycle. If such knowledge already in the curricula, their applicability is slow in coming. However, decree 1054 PR/MEN of 2 October 1972 gives instructions as to the practice of the EPS primary school in Gabon. Theorder 009 mandates alsothe teaching of physical education in primary school and decree 008 specifies the coefficient in this field of instruction in primary school.

Our results have also highlighted the lack of infrastructure and educational materials. 
Regarding infrastructure, only political will and synergy between the Ministry of National Education and the Youth and Sports can make a significant improvement to the breach. As for the educational materials the same approach should be adopted. For this, you need a real rehabilitation of the EPS to expand it. Besides, Soppelza and Albaret [7] stressed that "the primary medium in EPS is not an idea, not a person but an institution, that is to say a history thing" (p. 63).

In addition, we found that the EPS primary school in Gabon is not visible at both teachers and parents. But this, according Vincent et al. [18], must participate in "the formation of a sports citizenship" Here the civic education cluster by the EPS has developed. Furthermore, if as we have later stated that the EPS included indeed among the academic disciplines, the field against by his practice is not in conformity: not respected hourly quota and inadequate practice time (post midday). Finally, our respondents affirmed the qualities of physical education in children. Why they cannot engage their learners in competitions organized by the FEGASS? We believe here that this is unwillingness on their part.

\section{Conclusion}

The results obtained in this study showed that those current trends in the teaching of PSE in Gabonese primary education revealed a real identity problem associated with a recognition problem at the highest level of state authorities including those of the Ministries of National Education and youth and sports. In addition, the data obtained from primary teacher noted the existence of different strategies of learning between the prescribed curriculum (the official instructions and all texts being law) and real curriculum symbolized. Difficulties observed in the rural area don't contribute to promoting this scholar discipline. Also, it is necessary that a good policy is implemented to reconsider the actual place of EPS in primary cycle.

\section{References}

[1] Crozier, M. and Friedberg, E. (2007) L'acteur et le système éducatif. Les contraintes de l'action collective. Editions du Seuil, Paris.

[2] Charpier, F. (1999) Les représentations sociales d'enseignant d'EPS...en quête de reconnaissance. Editions Revues EPS, Paris.

[3] Trudeau, F. and Shephard, R.J. (2008) Physical Education. School Physical Activity, School Sports and Academic Performance. Assessment in Education, 15, 257-274.

[4] Taras, H. (2005) Physical Activity and Student Performance at School. Journal of School Health, 75, 214-218. http://dx.doi.org/10.1111/j.1746-1561.2005.00026.x

[5] Jodelet, D. (2004) Représentations sociales de l'EPS: Un domaine en extension. In: Jodelet, D., dir., Les représentations sociales, $9^{\mathrm{e}}$ édition, Presses Universitaires de France, Paris, 168192.

[6] Sheldon, S. (2003) Linking School-Family-Community Partnerships in Urban Primary Schools to Pupils Achievement on State Tests. The Urban Review, 35, 149-165. http://dx.doi.org/10.1023/A:1023713829693

[7] Soppelza, M. and Albaret, L.J. (2009) Pupil Assessment Capacities of Fitness. Journal of 
Teaching in Physical Education, 28, 326-342.

[8] Wirthner, B. (2014) Les difficultés de l'évaluation en éducation physique. Le cas des savoirs d'accompagnement à l'école primaire. Vie Pédagogique, 110, 45-49.

[9] Simon, M. and Forgette-Girouse, R. (2004) Vers une utilisation rationnelle du dossier d'appre-ntissage en EPS. Mesureet Evaluationen Education, 26, 27-40.

[10] Dunet, F. (1996) Sociologie de l'expérience scolaire. Editions du Seuil, Paris.

[11] Flahaut, R. (2013) Biostatistiques au quotidien. Editions Flammarion Médecine/Sciences, Paris.

[12] Sokal, R.F. and Rohlf, S.W. (1995) Biometry. 7th Edition, Freeman and Co., Francisco.

[13] Del Loubet Bayle, M. (2012) Quelle place de l'enseignement de l'Education Physique et Sportive en France? Cas du cycle primaire. Pédagogie Française, 31, 160-165.

[14] Lahire, B. (2008) La forme scolaire dans tous ses états. Revue Suisse des Sciences de PEducation, 30, 229-258.

[15] Moliner, P. (2001) Formation et stabilisation des représentions sociales. Presses Universitaires de Grenoble, Grenoble.

[16] Ntsame-Edjo, F. (2001) Les filiations entre les programmes d'histoire, de géographie et d'éducation physique des lycées et collèges du Gabon. Université de Laval, Québec.

[17] Pontais, C. (2005) Point de vue-Les enjeux de l'éducation physique et sportive en tant que discipline scolaire. Informations Sociales, 1, 67-71.

[18] Vincent, G., et al. (1994) Sur la théorie de la forme scolaire. Presses Universitaires de Lyon, Lyon. for you:

Accepting pre-submission inquiries through Email, Facebook, LinkedIn, Twitter, etc.

A wide selection of journals (inclusive of 9 subjects, more than 200 journals)

Providing 24-hour high-quality service

User-friendly online submission system

Fair and swift peer-review system

Efficient typesetting and proofreading procedure

Display of the result of downloads and visits, as well as the number of cited articles

Maximum dissemination of your research work

Submit your manuscript at: http://papersubmission.scirp.org/

Or contact jss@scirp.org 